\title{
Ectopic and extranumerary parathyroid glands location in patients with hyperparathyroidism secondary to end stage renal disease ${ }^{1}$
}

\author{
Localização de paratireóides ectópicas e extranumerárias em pacientes com \\ hiperparatireoidismo secundário à insuficiência renal crônica
}

\author{
Elaine Maria Santos Gomes ${ }^{2}$, Reinaldo Cavalcante Nunes ${ }^{2}$, Paulo Gustavo Sampaio Lacativa², Mirella Hansen deAlmeida ${ }^{3}$, \\ Felipe Malzac Franco ${ }^{4}$, Christianne Toledo Souza Leal ${ }^{2}$, Pedro José de Mattos Patrício Filho ${ }^{5}$, Maria Lucia Fleiuss \\ Farias $^{6}$, Manuel Domingos da Cruz Gonçalves ${ }^{7}$ \\ 1. Department of Internal Medicine, Divisions of Endocrinology and Nephrology and Department of Surgery of Clementino Fraga Filho \\ University Hospital (HUCFF) Federal University of Rio de Janeiro (UFRJ), Brazil. \\ 2. Fellow Master degree, Postgraduation Program in Endocrinology (UFRJ), Brazil. \\ 3. Fellow PhD degree, Postgraduation Program in Endocrinology (UFRJ), Brazil. \\ 4. Graduate Student (UFRJ), Brazil. \\ 5. Master in Nephrology (UFRJ), Brazil. \\ 6. Associate Professor, Division of Endocrinology (UFRJ), Brazil. \\ 7. Associate Professor, Department of Surgery (UFRJ), Brazil.
}

\begin{abstract}
Supranumerary or ectopic parathyroid glands are the main cause of persistent hyperparathyroidism (HPT) in patients with end stage renal disease (ESRD) submitted to parathyroidectomy (PTx). Purpose: To evaluate the prevalence and location of parathyroid glands in these patients. Methods: Thirty-five patients with ESRD and severe secondary hyperparathyroidism (HPT2) had been submitted to total PTx at HUCFF from December 2001 to July 2005. Surgery was always performed by the same surgeon, who described in details the location of the glands. Results: Sixteen patients (45.7\%) had ectopic glands, which were also extranumerary in five of them (14.3\%). The most common locations were the thyroid parenchyma (33.3\%), thyroid-thymus conduit (18.5\%), and thymus (14.8\%). Before PTx, the sensibility of ultrasonography and scintigraphy with technetium-99m Sestamibi was low (48.3\% and 35.3\%, respectively). Moreover, 51.4\% of the nodules found at US were thyroid nodules. However, $99 \mathrm{mTc}$-Sestamibi was useful to identify ectopic glands in those two patients with persistent HPT after PTx. Conclusion: The presence of extranumerary and ectopic parathyroid glands in HPT2 is sufficiently important to justify their exhaustive search. As the preoperative image exams present low sensibility to locate them, it is necessary to develop an exploratory routine embracing the most common sites of location.
\end{abstract}

Key words: Hyperparathyroidism, secondary. Renal insufficiency, chronic. Parathyroid glands. Parathyroidectomy.

\section{RESUMO}

A principal causa cirúrgica de persistência da doença após paratireoidectomia no hiperparatireoidismo secundário à insuficiência renal crônica (HPT2) é a existência de paratireóides supranumerárias e/ou ectópicas. Objetivo: Avaliar o número, prevalência de ectopia e localizações mais comuns das paratireóides nestes pacientes. Métodos: Acompanhamos prospectivamente pacientes com HPT2, submetidos à paratireoidectomia no HUCFF, entre dezembro/2001 e julho/2005. Todos foram operados pelo mesmo cirurgião, que descreveu detalhadamente a localização das paratireóides encontradas. Resultados: Foram avaliados 35 pacientes: em cinco (14,3\%) foi encontrada uma quinta glândula, supranumerária; dezesseis (45,7\%) possuíam glândulas ectópicas; as localizações mais comuns foram parênquima intratireoidiano (33,3\%), trajeto conduto tireotímico $(18,5 \%)$ e timo $(14,8 \%)$. As principais glândulas ausentes na presença de ectopia foram as inferiores esquerdas $(29,6 \%)$ e direitas $(25,9 \%)$. A sensibilidade da ultra-sonografia e da cintigrafia com sestamibi na detecção dos nódulos foi baixa (48,3\% e 35,3\%, respectivamente). Além disso, 51,4\% das ultra-sonografias mostraram incidentalomas tireoidianos. Conclusão: A presença de paratireóides supranumerárias e ectópicas no HPT2 é suficientemente relevante para justificar sua procura exaustiva. Como os exames de imagem pré-operatórios contribuem muito pouco para localizálos, é necessário que se desenvolva uma rotina de exploração abrangendo as localizações mais comuns.

Descritores: Hiperparatireoidismo secundário. Insuficiência renal crônica. Glândulas paratireóides. Paratireoidectomia. 


\section{Introduction}

Secondary hyperparathyroidism (HPT2) is one of the most important morbidity causes in patients with End Stage Renal Disease (ESRD) due to pathological fractures, bone deformities, and to decreased surviving time. Active vitamin D (1,25 dihydroxyvitamin D) deficiency and alterations in renal tubular function interfere with the calcium - phosphate homeostasis, thus causing hypocalcemia and hyperphosphatemia. These biochemical alterations lead to a permanent stimulation of synthesis and release of parathyroid hormone (PTH) leading to hypertrophy and hyperplasia of parathyroid cells ${ }^{1}$.

Most patients with HPT2 due to ESRD do not respond to clinical treatment and, after some years on dialysis, will need parathyroidectomy ${ }^{2}$. All parathyroid glands must be removed during the surgical approach, as even the ones that appear small and normal macroscopically may be responsible for persistence and/ or recurrence of disease in the future ${ }^{3}$.

Surgical failure happens in 10 to $30 \%$ of cases $^{4}$ beside the growing surgical expertise in parathyroidectomy. Incomplete identification of all parathyroids is the most important cause ${ }^{4-6}$ and that is why ectopic glands are a big challenge. Therefore, even if the four parathyroids usually located close to the thyroid gland are identified and removed, the risk of persistence and recurrence of hyperparathyroidism still exists due to ectopic extranumerary glands.

Preoperative imaging methods do not have high enough sensibility to detect all glands in HPT2. Perioperative serum PTH measurements help to diminish recurrence and persistence incidence. Yet, it still is an expensive procedure not available in all centers.

The purpose of this study is to define the most common sites of ectopic parathyroids in subjects with HPT2 due to ESRD and help surgeons to establish a routine for cervical exploration in order to identify ectopic and/ or extranumerary parathyroid glands.

\section{Methods}

Patients with ESRD and severe secondary hyperparathyroidism were recruited from hemodyalisis centers in the city of Rio de Janeiro, Brazil. They were studied at Clementino Fraga Filho University Hospital from December 2001 to July 2005 according to a protocol established by the Divisions of Endocrinology and Nephrology and the Department of Surgery. Inclusion criteria for parathyroidectomy were: serum PTH levels 10 times the upper normal range; non responsiveness to oral medications (high doses of calcitriol and calcium carbonate) and one or more of the following: persistent hypercalcemia despite discontinuation of calcium and calcitriol, persistent hypercalcemia with symptoms after kidney transplantation; calcium $\mathrm{x}$ phosphorus product $>70(\mathrm{mg} / \mathrm{dL})^{2}$; bone pain non responsive to oral treatment; pathological fractures; bone deformities; ectopic calcifications; incapacitant arthritis or periarthrites; tendons rupture; untreatable pruritus; brown tumors (when urgent surgical removal of the mass was needed). High persistent levels of serum PTH after calcitriol adjustment was considered a non response to clinical treatment (serum calcium corrected for albumin was 9 to $10 \mathrm{mg} / \mathrm{dL}$ ); or impossibility of using calcitriol due to hypercalcemia or hyperphosphatemia ${ }^{7}$. Repeated measurements of serum PTH and typical hyperparathyroidism alterations in skeleton radiographs confirmed HPT2. Thirty-seven subjects were submitted to parathyroidectomy. Two were excluded from this study: one because perioperative data were lost, and the other because only two parathyroid glands were identified, and hyperparathyroidism persisted. Instead of a second parathyroidectomy, this patient was submitted to kidney transplantation. Hemodyalisis data were revised when necessary in the hemodyalisis centers. All participants went through a parathyroid ultrasound scan and eight had a scintigraphy with sestamibi $99 \mathrm{mTc}$ before surgery. However, the preoperative imaging did not take place at HUCFF, neither was performed by the same radiologist.

Parathyroidectomy was perfomed by the same surgeon, an expert in this procedure. The same surgical technique was applied to all subjects: total parathyroidectomy with heterotopic autotransplantation. Parathyroid fragments were implanted in the forearm musculature at the opposite side of the arterious venous fistula. Perioperative data were described in details as well as the number and exact location of the glands. Using the thyroid gland as a reference, topic glands were considered the ones located in the superior and inferior right and left horns.

Any gland found in a different position was considered to be ectopic, including those in the thyroid parenchyma, within the thyroid capsule. All glands were examined after inclusion in paraffin. Histopathologic exam was performed by the same pathologist, and re-checked by a second one, both experts in parathyroid pathology at HUCFF. Blood samples were collected between 7 and 9 hours A.M. after overnight fasting the day before parathyroidectomy, two or three days after surgery, and then at 1, 3, 6 and 12 months, to confirm the surgical cure of HPT2. Serum calcium and phosphate were measured by routine methods and intact PTH was determined by an immunoradiometric assay using a kit DSL, Diagnostic Corp., California, USA (normal range: $7-53 \mathrm{pg} / \mathrm{ml}$ ). Subjects with serum PTH levels less than $300 \mathrm{pg} / \mathrm{ml}$ were considered cured. Recurrence of HPT2 would be confirmed if serum PTH levels increased above $300 \mathrm{pg} /$ $\mathrm{ml}$ after having normalized with surgery ${ }^{8}$. Cases of persistent or recurrent HPT2 would be re-tested with $99 \mathrm{mTc}-$ Sestamibi before a second parathyroidectomy. 
Analysis of data was done using SPSS 10.0 statistical package for Windows (SPSS Chicago, IL). This study was approved by the Ethic Committee of HUCFF Medical School of UFRJ. Each participant signed a written consent form before enrollment in the study.

\section{Results}

Thirty-five patients were submitted to parathyroidectomy. Twenty-one were females $(60 \%)$ and 14 males $(40 \%) ; 22$ non-white $(62.8 \%)$ and 13 whites $(37.2 \%)$. Mean age was $46.37 \pm 12.15$ years (range 24 to 77 years). Mean hemodyalisis time before surgery was $8.94 \pm 3.25$ years (range 2.33 to 18.75 years). The causes of ESRD were systemic arterial hypertension in 18 subjects $(51.4 \%)$, glomerulonephritis in $5(14.3 \%)$, systemic lupus erythematous in $4(11.4 \%)$, policystic kidney disease in $2(5.7 \%)$; diabetes mellitus, nephrolitiasis and renal tuberculosis in 1 subject each (2.9\%); unknown cause in 3 (8.6\%). Mean serum PTH levels were $2424.5 \pm 1213.5 \mathrm{pg} / \mathrm{ml}$ (range 584 to 5344 ). Twenty-eight subjects $(80.0 \%)$ had four glands, five $(14.3 \%)$ had supranumerary glands and two (5.7\%) had three glands. Sixteen patients $(45.7 \%)$ had ectopic glands (including those with extranumerary glands). A total of 143 glands were removed, 27 of which (18.9\%) were ectopic, including five extranumerary. In these cases of ectopic glands, the inferior parathyroids were the most common glands not found at their usual location (15 inferior versus 7 superior glands - Table 1). Ectopic glands were mostly found in the thyroid parenchyma $(33.3 \%)$, thyroid-thymus conduit $(18.5 \%)$, and thymus (14.8\% - Table 2).

Cervical ultrasound scans performed in all patients before the surgical procedure were able to identify only 69 of the 143 parathyroids, with a sensibility of $48.3 \%$. In 18 subjects $(51.4 \%)$, thyroid nodules were found at US; all them were surgically removed, but none corresponded to the parathyroids located inside the thyroid parenchyma. Eight patients were evaluated with $99 \mathrm{mTc}-$ Sestamibi before parathyroidectomy.

TABLE 1 - Parathyroids that were not in their usual location in patients with ectopic glands

\begin{tabular}{lccc}
\hline Parathyroid & Topic & Ectopic & Total \\
\hline Superior - Right & $30(88.2 \%)$ & $4(11.8 \%)$ & $34 *$ \\
Superior - Left & $32(91.4 \%)$ & $3(8.6 \%)$ & 35 \\
Inferior - Right & $27(79.4 \%)$ & $7(20.6 \%)$ & $34 *$ \\
Inferior - Left & $27(77.1 \%)$ & $8(22.9 \%)$ & 35 \\
Subtotal & $116(84.1 \%)$ & $22(15.9 \%)$ & 138 \\
Extra numerary & 0 & 5 & 5 \\
\hline Total & $116(81.1 \%)$ & $27(18.9 \%)$ & 143 \\
\hline
\end{tabular}

* Absent in two patients with only 3 glands.
The method detected only 12 out of the 34 parathyroids found at surgery in these patients, which corresponds to a sensibility of $35.3 \%$. A total of ten ectopic glands were detected in these subjects, but none was identified by $99 \mathrm{mTc}-$ Sestamibi. However, all parathyroids seen in the $99 \mathrm{mTc}$-Sestamibi scan were confirmed by a positive histopathologic analysis, a specificity of $100 \%$. Two patients maintained elevated serum PTH levels after surgery and were studied with $99 \mathrm{mTc}$-sestamibi scan in order to localize the remanescent gland. The first subject had a parathyroid gland located in the carotid artery sheath (superior mediastinum) and the second subject had an ectopic gland inside the thyroid parenchyma. The two patients went through parathyroidectomy again and were cured, assuring the $99 \mathrm{mTc}-$ Sestamibi scan a sensibility and specificity of $100 \%$ as a postoperative exam.

TABLE 2 - Most common locations of ectopic parathyroid glands

\begin{tabular}{lcc}
\hline Location & $\mathbf{n}^{\mathbf{0}}$ & $\begin{array}{c}\text { Percentage } \\
(\mathbf{\%})\end{array}$ \\
\hline Thyroid parenchyma & 9 & 33.3 \\
Thyreothymus conduct & 5 & 18.5 \\
Thymus & 4 & 14.8 \\
Carotid artery sheath & 2 & 7.4 \\
Mediastinum & 2 & 7.4 \\
Lying by the esophagus & 2 & 7.4 \\
Lateral to the thyroid gland & 1 & 3.7 \\
Retropharyngeal space & 1 & 3.7 \\
Lying by recurrent laryngeal nerve & 1 & 3.7 \\
\hline
\end{tabular}

\section{Discussion}

Secondary hyperparathyroidism due to ESRD is the best example to analyze parathyroid glands. There is a high prevalence of this disease and all glands are stimulated and enlarged. An average normal parathyroids weighs approximately 30 to $50 \mathrm{mg}$, whereas in HPT2 due to ESRD they can achieve $1005 \mathrm{mg}$, varying from 100 to 7150 grams ${ }^{9}$. Patients often report a prolonged time on hemodyalisis, present very high levels of serum PTH and do not respond to clinical treatment. In our population, duration of dialysis prior to parathyroidectomy was longer than reported in literature ( 8.94 versus 5.4 years) ${ }^{10,11}$. As PTH hypersecretion is proportional to the degree of parathyroid hyperplasia ${ }^{12}$, we can assume that all glands were stimulated to grow for a long period of time. Thus, it seems almost impossible that an experient surgeon could not find all topic parathyroids in these patients with HPT2, as even in cases of primary hyperparathyroidism due to diffuse but less severe hyperplasia, all parathyroids can be identified and persistence or recurrence are very rare. These facts 
reinforce the importance of searching for ectopic and supranumerary glands in HPT2. Human beings usually have four parathyroid glands ${ }^{9}$. Statistical analyses of autopsies demonstrate supranumerary parathyroids in $2.5-12.7 \%$ of normal individuals ${ }^{13}$. During parathyroid surgery, 2 - $5 \%$ cases of extranumerary glands are reported 9 . The high incidence of supranumerary glands in the present study can be explained for the facility in finding hyperplasic glands during surgical exploration of patients with HPT2, as previously reported ${ }^{13}$. On the other hand, as less than four parathyroids are very rare ${ }^{9}$, surgeons must look for ectopic glands whenever only three or two parathyroids are identified.

In our patients, the incidence of ectopic parathyroids was slightly higher than that described by Mariani et al. $(15-20 \%)^{9}$. The inferior parathyroids were not frequently found in the usual place when ectopic glands were demonstrated. The explanation for this fact is embryological, since the parathyroids originate from endoderm of third and fourth brachial arcs and the relative position is inverted during the migration: glands that were originally positioned in the fourth brachial arc continue together with thyroid and will be located in the posterolateral surface of superior lobes, and those positioned in the third arc go along with thymus and will be found at the posterior-lateral surface of inferior thyroid lobes. Because of more extensive migration, the inferior parathyroids are more frequently ectopic, some of them located in the thyroid-thymus conduit ${ }^{9}$. Superior glands are uncommonly ectopic, but a case of retropharyngeal localization was described by Thompson ${ }^{14}$

Some authors do not recommend preoperative imaging to localize the parathyroids because it does not interfere with the surgical outcome since the surgeon has enough experience ${ }^{14}$. However, others defend the utility of these methods, such as ultrasound scan, nuclear magnetic resonance, computed tomography, scintigraphy with 99mTc-Sestamibi, and others. Recent data showed that sensibility differs among these methods, but there is no consensus on which one is preferable.

Nuclear magnetic resonance or computed tomography are especially indicated in cases of persistent or recurrent hyperparathyroidism, once they offer a better anatomic definition of the mediastinum and identification of parathyroids at retrotracheal, retropharyngeal and other spaces. Comparing to ultrasound $\operatorname{scan}^{9} .{ }^{201} \mathrm{TICI}$ single photon emission computed tomography (SPECT) and some other exams are not more effective than the traditional ones, mostly $99 \mathrm{~m}$ Tc-Sestamibi in these cases ${ }^{13}$.

The importance of perioperative ultrasound scans and gamma-probe evaluation to detect remanent parathyroids is questionable. The perioperative measurement of serum PTH seems more useful in determining the surgical cure or persistence of hyperparathyroidism, as a significant fall in serum PTH levels in expected 20 minutes after parathyroidectomy ${ }^{15}$. We found a low sensibility of ultrasound scan in localizing parathyroids: even excluding those located at the mediastinum, US could not detect the ectopic glands. Besides, the presence of nodular goiter reported in more than half of cases contributed to the low specificity. These disappointing results may be explained by our study limitations; ultrasound scans were not performed by the same radiologist or with the same machine. Yet, this is a common setting in our practice. Concerning scintigraphy with $99 \mathrm{mTc}$-Sestamibi, the specificity was $100 \%$ but with a low sensibility. This method was especially useful in the two cases of persistent disease. However, we studied few patients, which limit these conclusions. In summary, the sensibility of preoperative ultrasound and $99 \mathrm{mTc}-$ Sestamibi scintigraphy suggests that surgeons should not rely on these exams, especially concerning number of glands and presence of ectopia. Thus, an exhaustive search is advised.

The most cost-effective and safest treatment of persistent or recurrent hyperparathyroidism is avoiding them in the first surgery, since a new parathyroid exploration is associated with more complications and lower cure rates comparing to the initial operation ${ }^{15}$. In order to have obtain better results in the first approach, the surgeon should know the commonest places of ectopic or supranumerary glands, and therefore explore the cervical region carefully.

We demonstrate that the most frequent localizations were thyroid parenchyma, thyroid-thymus conduit and thymus. These findings associated with the high incidence of thyroid incidental nodules showed in ultrasound imaging, bring up the discussion of which decision is the right one - remove or not these nodules. The first option would prolong surgery time and increase the chances of complications, but not removing them may raise the risk of persistent or recurrent hyperparathyroidism.

According to Gonçalves ${ }^{14}$, when a parathyroid is not found in its usual location, thyroid lobes must be carefully examined looking for nodules, which should be extirpated for frozen analyzes. Thymus removal is the next step, since ectopic parathyroids can be found intrathymus or in the superior mediastinum. The same routine procedure is recommended by other authors ${ }^{13}$. Surgical exploration must also be extended to the superior mediastinum and the area around the esophagus, mainly at the left side ${ }^{13-14}$

In cases of recurrence and/ or persistence of hyperparathyroidism, a scintigraphy with $99 \mathrm{mTc}-$ Sestamibi should be done. For some authors, this exam has the highest sensibility rates concerning location of the glands ${ }^{13}$. Our group had an excellent experience with this exam performed postoperatively, in the only two subjects with persistent HPT2. 


\section{Conclusion}

The presence of extranumerary and ectopic parathyroid glands in HPT2 is sufficiently important to justify their exhaustive search. As the preoperative image exams contribute very little to locate them, it is necessary to develop an exploratory routine that involves the most common sites of the glands. Since the most common locations were the thyroid parenchyma, thyroid-thymus conduit, and thymus we suggest a careful search of the cervical region, removal of thymus and all the incidental thyroid nodules.

\section{References}

1. Bushinsky DA. Calcium, magnesium, and phosphorus: renal handling and urinary excretion. In: Favus MJ, editor. Primer on the metabolic bone disease and disorders of mineral metabolism. 4ed. Philadelphia: Lippincott Williams \& Williams; 1999. p 67-74.

2. Akerström G, Malmaeus J, Bergström R. Surgical anatomy of human parathyroid glands. Surgery. 1984; 95: 14.

3. Tominaga Y, Katayama A, Sato T, Matsuoka S, Goto N, Haba T, Hibi Y, Numano M, Ichimori T, Uchida K. Reoperation is frequently required when parathyroid glands remain after initial parathyroidectomy for advanced secondary hyperparathyroidism in uraemic patients. Nephrol Dial Transplant. 2003; 18: III 65-70.

4. Rothmund M, Wagner P. Reoperations for persistent and recurrent secondary hyperparathyroidism. Ann Surg. 1988; 207: 310-4.

5. Dotzenrath C, Cupisti K, Goretzki E, Mondry A, Vossough A, Grabensee B, Roher HD. Operative treatment of renal autonomous hyperparathyroidism: cause of persistent or recurrent disease in 304 patients. Langenbecks Arch Surg. 2003; 387(9-10): 348-54.
6. Kassler M, Avila JM, Renoult E, Mathieu P. Reoperation for secondary hyperparathyroidism in chronic renal failure. Nephrol Dial Transplant. 1991; 6: 176-9.

7. Lacativa PGS, Patrício Filho PJM, Gonçalves MDC, Farias MLF. Indicações de paratireoidectomia no hiperparatireoidismo secundário à insuficiência renal crônica. Arq Bras Endocrinol Metab. 2003; 47: 644-53.

8. Bolton K, Coburn JW, Chertow GM. K/DOQI clinical practice guidelines for bone metabolism and disease in chronic kidney disease. National Kidney Foundation Kidney Disease Outcomes Quality Initiative (K/DOQI); 2002. Available from URL: <http://www.kidney.org/ professionals $/ \mathrm{kdoqi} /$ guidelines bone/index.htm $>$.

9. Mariani G, Gulec SA, Rubello D, Boni G, Puccini M, Pelizzo MR, Manca G, Casara D, Sotti G, Erba P, Volterrani D, Giuliano AE. Preoperative localization and radioguided parathyroid surgery. J Nucl Med 2003; 44(9): 1443-58.

10. Malberti F, Marcelli D, Conte F, Limido A, Spotti D, Locatelli F. Parathyroidectomy in patients on renal replacement therapy: an epidemiologic study. J Am Soc Nephrol. 2001; 12(6): 1242-8.

11. Leapman SB, Filo RS, Thomalla JV, King D. Secondary hyperparathyroidism: the role of surgery. Am Surg. 1989; 55(6): 359-65.

12. Parfitt AM. The hyperparathyroidism of chronic renal failure: a disorder of growth. Kidney Int. 1997; 48: 259-72.

13. Numano M, Tominaga Y, Uchida K, Orihara A, Tanaka Y, Takagi H. Surgical significance of supranumerary parathyroid glands in renal hyperparathyroidism. World J Surg. 1998; 2: 1098-103.

14. Gonçalves MDC. Localização de paratireóides. In Tratado de endocrinologia e cirurgia endócrina. 1ed. Rio de Janeiro: Guanabara Koogan SA; 2001. p 674-8.

15. Caron NR, Sturgeon C, Clark OH. Persistent and recurrent hyperparathyroidism. Curr Treat Options Oncol. 2004; 5(4): 335-45.

\section{Correspondence:}

Elaine Maria dos Santos Gomes, MD.

Division of Endocrinology, Clementino Fraga Filho University Hospital (HUCFF)

Federal University of Rio de Janeiro (UFRJ), Brazil.

Brigadeiro Trompovski Avenue, Ilha do Fundão, Rio de Janeiro-RJ

21941-590

Phone: (55 21) 2562-2748/2005-1710 - Fax: (55 21) 2590-2958

elainemariagomes@globo.com
Conflict of interest: none Financial source: none

Received: November 24, 2006

Review: December 19, 2006

Accepted: January 16, 2007

\section{How to cite this article:}

Gomes EMS, Nunes RC, Lacativa PGS, Almeida MH, Franco FM, Leal CTS, Patrício Filho PJM, Farias MLF, Gonçalves MDC. Ectopic and extranumerary parathyroid glands location in patients with hyperparathyroidism secondary to end stage renal disease. Acta Cir Bras. [serial on the Internet] 2007 Mar-Apr;22(2). Available from URL: http://www.scielo.br/acb 